\title{
A BÍBLIA NO MUNDO E NO BRASIL E A INCIDÊNCIA DE MARCAS IDEOLÓGICO-DOUTRINÁRIAS NAS PRIMEIRAS TRADUÇÕES BRASILEIRAS COMPLETAS
}

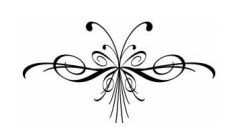

MARCELO RAUPP

Resumo: este artigo visa apresentar um resumo da tese de doutorado defendida pelo autor em 20/03/2015 no Programa de Pós-Graduação em Estudos da Tradução da Universidade Federal de Santa Catarina. A pesquisa que culminou na tese teve duplo objetivo: 1) mapear a transmissão e a tradução da Bíblia no Brasil e no mundo e 2) pôr em evidência as marcas ideológico-doutrinárias que podem ser observadas nas primeiras traduções bíblicas completas feitas por diferentes grupos religiosos de matriz judaico-cristã presentes em território brasileiro.

Palavras-chave: transmissão da Bíblia; tradução da Bíblia; viés ideológico-doutrinário dos tradutores.

\begin{abstract}
: this article aims to present an overview of the doctoral thesis defended by the author in 03/20/2015 at the Graduate Program in Translation Studies at the Federal University of Santa Catarina. The research that resulted in the thesis had dual purpose: 1) to map the transmission and translation of the Bible in Brazil and worldwide and 2) to highlight the doctrinal ideology brands that can be observed within the first complete Brazilian biblical translations, made by different Judeo-Christian religious groups present in Brazil.
\end{abstract}

Keywords: Bible transmission; Bible translation; translators' doctrinal ideologies.

\section{Dois objetivos}

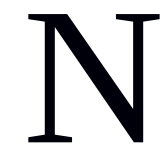

ossa tese foi calcada em cima de dois objetivos: chamamos um de primário, e o outro, de secundário. O objetivo secundário, mas não menos importante para o conjunto da obra, diz respeito à história da transmissão e da tradução da Bíblia no mundo e no Brasil. A partir deste objetivo, pretendemos fornecer um panorama histórico abordando tópicos como o surgimento da Bíblia, seus manuscritos mais antigos, as traduções que mais se destacaram ao longo da História e as reconstituições que culminaram nos textos fontes que servem de base para os projetos tradutórios. Já no que respeita ao

Scientia Traductionis, $n .16,2014$ http://dx.doi.org/10.5007/1980-4237.2014n16p49

publicado em 20/06/2016 
objetivo primário, este tem a ver com a multiplicidade de traduções bíblicas. Com este objetivo, pretendemos mostrar que as traduções dessa obra não estão imunes à ideologia doutrinária dos tradutores. Para tanto, valemo-nos de uma análise comparativa que levou em conta trechos da primeira tradução completa da Bíblia feita pelos grupos religiosos judaico-cristãos presentes no Brasil, pelo fato de geralmente ser nas traduções pioneiras que as marcas ideológico-doutrinárias são mais evidentes. E nossa análise focalizou as passagens que mais costumam gerar disputas entre esses grupos religiosos.

\subsection{O que nossa tese pretende}

Quanto ao objetivo primário, convém deixar claro o que pretendemos e o que não pretendemos, a fim de evitar mal entendidos. Assim, nossa tese pretende:

a) Mostrar que há versões da Bíblia revestidas de uma espécie de direcionamento ideológico-doutrinário em pontos específicos do texto de chegada.

b) Ser uma estimuladora à reflexão de que as versões da Bíblia não estão livres de manifestarem posicionamentos ideológico-doutrinários.

\subsection{O que nossa tese não pretende}

a) Ser uma promotora ou desmerecedora de nenhum dos grupos religiosos que estão por trás das versões bíblicas que compõem o nosso corpus.

b) Ser uma promotora da ideia generalista de que toda tradução, seja da Bíblia ou de qualquer outro tipo de texto, possui manipulações ideológicas.

\section{A história da transmissão e da tradução da Bíblia no mundo e no Brasil}

As próximas seções contêm um resumo do material referente ao objetivo secundário da nossa tese, ou seja, aquele que abordará temas como o surgimento da Bíblia, seus manuscritos mais antigos, as traduções que mais se destacaram ao longo da História, tanto no mundo quanto no Brasil, e as reconstituições que culminaram nos textos fontes que hoje servem de base para os projetos tradutórios.

\subsection{O surgimento da Bíblia}

De acordo com Long (2005, p. 13), os textos religiosos têm sua origem na comunicação oral, pois eram transmitidos quase exclusivamente de boca em boca. Quanto ao chamado Antigo Testamento (doravante AT), cuja língua original é o hebraico, Beckwith (1998, p. 71-72) postula que foi Moisés quem teria começado a escrever, provavelmente com base nas tradições orais e escritas que circulavam na sua época, parte do material que mais tarde seria aproveitado na compilação dos cinco primeiros livros da Bíblia, a saber, Gênesis, Êxodo, Levítico, Números e Deuteronômio. Reese e Klassen (2003, p. 101, 255) sugerem que Moisés teria vivido de 1543 a.C. a 1423 a.C..

No que diz respeito ao chamado Novo Testamento (doravante NT), originalmente escrito em grego, Lenhardt e Collin (1997, p. 7) informam que o evangelho que Jesus de Nazaré mandou anunciar a todas as nações primeiro foi pregado de forma oral, antes de ser consignado por escrito pelos seus primeiros 
seguidores, dando origem aos livros que mais tarde formariam o NT. Deste modo, se aceitarmos essa cronologia, pode-se estimar que o processo de composição de toda a Bíblia cristã levou aproximadamente 1600 anos: da segunda metade do século XVI a.C., época em que Moisés teria vivido, até meados de 90 d.C., que é quando o último livro do NT (o Apocalipse) teria saído da pena do apóstolo João.

\subsection{Os manuscritos da Bíblia}

Os manuscritos autógrafos da Bíblia se perderam. Os que se preservaram e chegaram até nós são centenas de cópias, feitas nas mais diferentes épocas da História.

\subsubsection{As cópias manuscritas mais antigas do AT}

a) Pentateuco Samaritano: a produção deste manuscrito se deve ao rompimento dos judeus com os samaritanos, fato que ocorreu por volta de 430 a.C..

b) Manuscritos do Mar Morto: tratam-se de centenas de documentos descobertos em Israel entre 1940 e 1950, produzidos ao longo de cerca de 200 a.C. a 68 d.C..

c) Manuscritos da Sinagoga do Cairo: produzidos entre 800 d.C. e 1400 d.C..

\subsubsection{As cópias manuscritas mais antigas do NT}

a) Códice Sinaítico e Códice Vaticano: produzidos em algum momento entre 300 d.C. e 350 d.C..

b) Códice Alexandrino e Códice Washingtoniano: produzidos em meados de 400 d.C..

c) Códice Efraimita: produzido em algum momento entre 400 d.C. e 500 d.C..

d) Códice Beza: produzido em meados de 500 d.C..

e) Códice Claromontano: produzido em algum momento entre 500 d.C. e 600 d.C..

2.3. O problema das cópias e a padronização do texto da Bíblia

Antes da invenção da imprensa, no século XV, a difusão da Bíblia nas línguas originais dependeu de cópias feitas a mão. Durante todo o tempo em que a Bíblia foi assim transmitida, os escribas alteraram certas passagens, acidental ou intencionalmente. Conforme Trebolle Barrera (1999, p. 439), essas alterações são inevitáveis de acontecer com um texto copiado inúmeras vezes. E é justamente em virtude delas que nem todos os manuscritos bíblicos hoje disponíveis concordam $100 \%$ entre si em determinadas passagens.

As alterações nos manuscritos da Bíblia são estudadas pela Crítica Textual, ciência que tem por meta recuperar a forma primeira das obras literárias antigas cujo original se perdeu, mediante o cotejamento de todas as cópias disponíveis. Sendo assim, as traduções da Bíblia que são feitas pelo mundo tem tomado como base obras compiladas a partir de um cotejamento feito entre centenas de manuscritos disponíveis. Tais obras compiladas objetivam reconstruir o texto original tal como teria se apresentado antes de os escribas introduzirem as alterações. 
2.4. Proposta de padronização para o AT, com base na Crítica Textual

a) Texto Massorético: é a única tradição textual a trazer todos os livros do cânon hebraico nas línguas originais. Foi preparado do século VI d.C. ao XI d.C.. Suas atuais edições críticas que mais têm se destacado são a Bíblia Hebraica Kittel (a edição mais recente foi lançada em 1951) e a Bíblia Hebraica Stuttgartensia (lançada em 1977).

2.5. Proposta de padronização para o NT, com base na Crítica Textual

a) Texto Recebido: é a primeira proposta de padronização. Começou a ser preparado no século XVI. Traz passagens que não constam nos manuscritos mais antigos.

b) Texto Crítico: começou a ser preparado no século XIX, quando vieram à luz antigos manuscritos gregos do NT, que não haviam sido considerados na compilação do Texto Recebido. Sua compilação mais recente é a Nestle-Aland, que já está na $28^{a}$ edição, lançada em 2012.

2.6. A tradução da Bíblia no mundo

A seguir, consta um panorama em ordem cronológica das traduções da Bíblia que mais se destacaram na Idade Antiga, na Idade Média e na Idade Moderna ${ }^{1}$.

- Septuaginta: tradução para o grego, levada a cabo do século III a.C. ao I a.C..

- Peshitta: tradução para o siríaco, feita do século I d.C. ao III d.C..

- Targuns: traduções para o aramaico, feitas do século I d.C. ao V d.C..

- Vetus Latina: tradução para o latim, feita no século II d.C..

- Traduções para o copta: feitas do século III d.C. ao IV d.C..

- Tradução do bispo Úlfilas para o gótico: levada a cabo no século IV d.C..

- Tradução para o etíope: feita do século IV d.C. ao V d.C..

- Vulgata: tradução para o latim, feita por São Jerônimo, no final do século IV d.C..

- Tradução para o armênio: veio à luz no século V d.C..

- Tradução para o georgiano: começou a ser feita no século V d.C..

- Tradução para o árabe: feita do século VII ao X.

- Tradução de Cirilo e Metódio para o eslavônico: levada a cabo no final do século IX.

- Tradução de Étienne de Anse para o provençal: feita do século XII ao XIII.

- Tradução de John Wycliffe para o inglês: lançada em 1382.

- Tradução de Jacques Lefèvre d'Étaples para o francês: veio a público em 1530.

${ }^{1}$ O início e o término de cada período da Histórica Ocidental que compreendem as traduções da Bíblia que apresentaremos são aqueles que são consenso entre os historiadores no que se refere à história da Europa, a saber: Idade Antiga: da invenção da escrita (entre 4000 a.C. e 3500 a.C.) até a queda do Império Romano do Ocidente (476 d.C.); Idade Média: de 476 até a tomada de Constantinopla pelos turcos otomanos (1453); Idade Moderna: de 1453 até o início da Revolução Francesa (1789). 
- Tradução de Martinho Lutero para o alemão: publicada em 1534.

- Tradução de Pierre Robert Olivétan para o francês: veio a público em 1535.

- Tradução de William Tyndale para o inglês: lançada em 1537.

- Bíblia de Genebra, tradução para o inglês: publicada em 1560.

- Tradução de Reina-Valera para o espanhol: veio a público em 1602.

- Tradução de Giovanni Diodati para o italiano: lançada em 1607.

- Bíblia Douay-Rheims, tradução para o inglês: publicada em 1610.

- Bíblia King James, tradução para o inglês: veio a público em 1611.

- Tradução de João Ferreira de Almeida para o português: lançada em 1753.

- Tradução de Antônio Pereira de Figueiredo para o português: publicada em 1790.

\subsection{A tradução da Bíblia no Brasil}

Apresentamos agora um panorama em ordem cronológica das traduções da Bíblia no cenário nacional. Procuramos abarcar desde as primeiras traduções, passando pelas versões em português realizadas em outros países e posteriormente publicadas no Brasil, até chegar às traduções nacionais completas $(\mathrm{AT}+\mathrm{NT})$ que mais se destacaram.

- Tradução de Joaquim Martins de Carvalho: é o primeiro projeto tradutório da Bíblia levado a cabo no Brasil, de 1845 a 1847. É uma tradução católica, feita com base na Vulgata de São Jerônimo, e abrangeu apenas o NT.

- Primeira revisão brasileira da tradução de João Ferreira de Almeida: foi lançada em 1879 e abarcou apenas o NT.

- Versão Almeida Revista e Corrigida: mais uma revisão brasileira do trabalho de Almeida, que veio a público em 1898. Dessa vez, abrangeu toda a Bíblia.

- Tradução de Francisco Rodrigues dos Santos Saraiva: primeira tradução de parte da Bíblia, com base no hebraico, feita em território brasileiro. Lançada em 1898, abarcou apenas o Livro dos Salmos e aparenta ser um trabalho interconfessional.

- Tradução de José Basílio Pereira: é uma tradução católica do NT, feita a partir da Vulgata, e publicada entre 1902 e 1910.

- Tradução de Duarte Leopoldo da Silva: tradução católica dos quatro evangelhos, em narrativa harmonizada, feita com base na Vulgata, e lançada em 1903.

- Tradução do Colégio da Imaculada Conceição: versão² católica dos quatro evangelhos e do livro de Atos. Veio a público em 1904 e usou a Vulgata como texto fonte.

- Tradução Brasileira: é o primeiro projeto tradutório de toda a Bíblia levado a cabo no Brasil. É uma tradução protestante, feita a partir das línguas originais, e publicada em 1917.

- Tradução de Huberto Rohden: veio a público em 1930. É a primeira tradução católica do NT, a partir do grego.

\footnotetext{
${ }^{2}$ Utilizaremos, intercambiavelmente, os termos versão e tradução como sinônimos.
} 
- Tradução da Editora Ave-Maria: primeira versão católica de toda a Bíblia realizada no Brasil. Lançada em 1959, é uma tradução indireta ${ }^{3}$ do francês, feita com base na versão dos Monges de Maredsous, da Bélgica.

- Versão Almeida Revista e Atualizada no Brasil: outra revisão brasileira do trabalho de João Ferreira de Almeida. Veio a público em 1959.

- Tradução de Meir Matzliah Melamed: é o primeiro projeto tradutório da Bíblia, com base no hebraico, destinado aos judeus tradicionais, ou seja, os judeus que rejeitam a ideia de que Jesus de Nazaré o Messias. O trabalho foi lançado em 1962 e abrangeu apenas o Pentateuco.

- A Bíblia mais Bela do Mundo: é a primeira tradução católica de toda a Bíblia, a partir das línguas originais. O trabalho foi publicado em fascículos semanais ilustrados, ao longo da década de 1960.

- Tradução do Novo Mundo das Escrituras Sagradas: primeira e única versão brasileira de toda a Bíblia destinada às Testemunhas de Jeová. Lançada em 1967, é uma tradução indireta, feita com base na versão inglesa destinada ao mesmo grupo religioso.

- Versão Almeida revisada de acordo com os melhores textos: publicada em 1967, é a quarta revisão do trabalho de João Ferreira de Almeida levada a cabo no Brasil.

- Tradução do Pontifício Instituto Bíblico de Roma: tradução católica de toda a Bíblia, lançada em 1967. Aparenta ser uma tradução indireta da versão em italiano.

- Tradução dos Missionários Capuchinhos: veio a público em 1968. É uma revisão brasileira de uma tradução católica portuguesa de toda a Bíblia, a partir das línguas originais.

- Bíblia de Jerusalém: tradução católica completa da Bíblia, publicada em 1981, feita com base nas línguas originais.

- Bíblia Viva: de cunho protestante e lançada em 1981, é uma versão integral da Bíblia que primou por um texto de chegada em linguagem acessível ao grande público. Demonstra ser uma tradução indireta da versão estadunidense intitulada Living Bible.

- Bíblia Vozes: tradução católica de toda a Bíblia, a partir das línguas originais, e disponibilizada ao público em 1982.

- Bíblia na Linguagem de Hoje: é o segundo projeto tradutório de toda a Bíblia, com base nas línguas originais, executado em território brasileiro por iniciativa protestante. O trabalho foi publicado em 1988 e teve como diferencial a preocupação em apresentar um texto em linguagem acessível aos leitores em geral.

- Almeida Edição Contemporânea: lançada em 1990, esta é mais uma revisão brasileira do trabalho de João Ferreira de Almeida.

- Bíblia Pastoral: feita a partir das línguas originais, é uma tradução católica completa da Bíblia, que veio a público em 1990. É a primeira iniciativa da Igreja Católica no Brasil em produzir uma tradução em linguagem acessível ao grande público.

\footnotetext{
${ }^{3}$ Grosso modo, uma tradução indireta é aquela feita não com base no texto original, mas em uma tradução dele. As versões da Bíblia feitas a partir da Vulgata de São Jerônimo são exemplos típicos de tradução indireta.
} 
- Tradução Ecumênica da Bíblia: publicada em 1994, esta é primeira versão brasileira completa da Bíblia a ter pretensões declaradamente interconfessionais. É uma tradução indireta, feita com base na versão francesa que leva o mesmo nome.

- Versão Almeida Corrigida Fiel: lançada em 1994, trata-se de outra revisão brasileira da tradução de João Ferreira de Almeida.

- Nova Versão Internacional: tradução protestante de toda a Bíblia, com base nas línguas originais, publicada em 2000.

- Tradução da CNBB: feita a partir das línguas originais, é uma tradução católica completa da Bíblia. O trabalho foi lançado em 2001.

- Bíblia do Peregrino: veio a público em 2002. É uma versão católica de toda a Bíblia, traduzida indiretamente da versão espanhola que possui o mesmo título.

- Bíblia Hebraica: primeira tradução de toda a Bíblia destinada ao Judaísmo tradicional. Feita com base nas línguas originais, foi publicada em 2006.

- Bíblia Sagrada de Aparecida: lançada em 2006, é mais uma tradução católica inédita de toda a Bíblica, calcada nas línguas originais.

- Versão Almeida Século 21: de orientação protestante, apresenta-se como uma "retradução" de toda a Bíblia, a partir das línguas originais, mas mantendo as linhas básicas do texto de João Ferreira de Almeida. O trabalho foi disponibilizado ao público em 2007.

- Versão Reina-Valera em Português: publicada em 2009, é uma versão protestante de toda a Bíblia, traduzida indiretamente da versão Reina-Valera em espanhol.

- A Torah e a B'rith Hadashah: veio a público em 2009 e é a primeira tradução de toda a Bíblia destinada aos judeus messiânicos, ou seja, os judeus que abraçam a ideia de que Jesus de Nazaré é o Messias. Foi feita com base no Texto Massorético e na antiga versão Peshitta.

- Bíblia Judaica Completa: outra versão de toda a Bíblia voltada para os judeus messiânicos. O trabalho foi lançado em 2010 e é uma tradução indireta da versão estadunidense que tem o mesmo nome.

- Bíblia Sagrada da Editora Escala: publicada em 2011, é uma das poucas versões bíblicas completas atualmente disponíveis a terem pretensões ecumênicas declaradas. Não se sabe ao certo quais fontes foram usadas nesta tradução, tampouco se foi feita a partir das línguas originais.

- A Mensagem: Bíblia em Linguagem Contemporânea: veio a público em 2011. É uma tradução indireta de cunho protestante, que abrangeu toda a Bíblia. A fonte usada foi a versão estadunidense que leva o mesmo título.

- Bíblia King James Atualizada: trata-se da mais recente versão brasileira inédita de toda a Bíblia que veio a público até a finalização da tese que serviu de base para o presente artigo. É uma tradução protestante, lançada em 2012, feita com base nas línguas originais, que procurou incorporar o estilo da King James inglesa. 


\section{As marcas ideológico-doutrinárias nas primeiras traduções brasileiras completas da Bíblia}

A partir daqui, apresentaremos um resumo do material concernente ao objetivo primário da nossa tese, a saber, aquele que diz respeito à incidência de marcas ideológico-doutrinárias nas primeiras traduções brasileiras completas da Bíblia.

\subsection{As decisões do tradutor e as marcas ideológicas no texto de chegada}

A eleição antecipada de uma determinada estratégia de tradução (literal ou livre, por exemplo) pode dar a entender que o tradutor terá controle sobre o processo tradutório. Superficialmente, isso até procede. No entanto, há boas razões para crer que esse controle não é absoluto, pois, da mesma forma que as escolhas idiossincráticas de todo indivíduo são influenciadas, na sua maioria, tanto pelo meio socioeconômico e cultural onde vive quanto pelos meios alternativos em que este opta por se inserir, não seria exagero pensar que isso também se reflete em várias medidas no trabalho de quem traduz.

Em outras palavras, é razoável admitir que haja vários motivos para crer que o tradutor é influenciado por uma série de fatores que definem sua maneira de traduzir, já que transportar um texto de uma língua para outra tem se mostrado uma imbricada atividade que envolve interpretação, transmutação, preenchimento de lacunas, produção de significados e, principalmente, apropriação do original. Assim, toda tradução parece implicar um grau de manipulação do texto fonte para um determinado objetivo, além de ser o resultado de uma complexa atividade que envolve uma série de variáveis e uma intensa negociação entre dois universos socioculturais.

É nesta lacuna que entram em cena as ideologias, as quais, segundo Hatim e Mason (1990, p. 161), encontram sua mais clara forma de expressão na linguagem, visto que a linguística crítica possui como elemento central a convicção de que a língua reproduz mesmo ideologias. Partindo desses pressupostos, parece aceitável admitir que haja certas traduções dotadas de marcas ideológicas em alguma medida, já que fica difícil não concordar que toda tradução, da mesma forma que o original, é uma autêntica manifestação da linguagem e, como tal, também pode ser um potencial meio transmissor de ideologias.

\subsection{Os impactos na tradução da Bíblia}

Hoje em dia, podemos encontrar muitos pensamentos divergentes sobre certos temas que são abordados na Bíblia, o que têm acumulado várias correntes interpretativas ao longo do tempo. Parte disso se deve ao fato de que, conforme postula Gohn (2001, p. 148), os textos religiosos são materiais linguísticos voláteis e polêmicos, o que de certa forma explica os embates que tem havido ao longo dos séculos envolvendo a interpretação e a tradução da Bíblia. E há boas razões para crer que a situação hoje não mudou. Por causa da facilidade de acesso a essa obra e do surgimento de novos grupos que nela se baseiam, suas interpretações e especificidades de tradução acabaram por se ampliar grandemente, tornando os embates ideológico-doutrinários ainda mais intensos. Dada essa divergência, não é de se estranhar que hoje sejam encontradas traduções da Bíblia produzidas para 
transmitir não apenas o conteúdo do texto fonte, mas ainda os posicionamentos dos tradutores. É nessa lacuna que residiu o objetivo primário da nossa tese.

\subsection{Exemplos de passagens bíblicas analisadas}

A seguir, consta uma amostra das passagens da Bíblia que analisamos, tomadas das primeiras traduções brasileiras completas dessa obra, a fim de levar a cabo nosso objetivo primário. Ao longo da tese, analisamos vinte e quatro passagens controvertidas. Mas, por uma questão de espaço, o que segue é um resumo da análise de apenas cinco delas.

\subsubsection{O corpus utilizado para atingir o objetivo primário}

- Tradução Brasileira (doravante TB): patrocinada por cristãos protestantes, foi publicada em 1917.

- Tradução da Editora Ave-Maria (doravante TEAV): veio a público em 1959 e é destinada aos cristãos católicos.

- Tradução do Novo Mundo das Escrituras Sagradas (doravante TNMES): lançada em 1967, tem as Testemunhas de Jeová como público-alvo.

- Tradução Ecumênica da Bíblia (doravante TEB): possui pretensões declaradamente ecumênicas, tendo sido publicada em 1994.

- Bíblia Hebraica (doravante BH): feita por judeus tradicionais, ou seja, aqueles que rejeitam a ideia de que Jesus de Nazaré é o Messias prometido nas páginas do chamado Antigo Testamento. Veio a público em 2006.

- A Torah e a B'rith Hadashah (doravante TBH): lançada em 2009, foi levada a cabo por judeus messiânicos, ou seja, aqueles que veem o Messias na pessoa de Jesus de Nazaré.

\subsubsection{A narrativa da criação}

Vejamos o que diz a tradução literal do hebraico para Gênesis 1:1-2, conforme Kohlenberger III (1987, p. 1):

1 No princípio criou Deus os céus e a terra. 2 Ora a terra era sem forma e vazia e trevas estavam sobre a superfície do abismo e o espírito de Deus pairava sobre a superfície das águas.

Agora vejamos como nosso corpus traduziu o sintagma "Espírito de Deus" (em hebraico: Ruach Elohim):

\begin{tabular}{l|l|l|l|l|l}
\multicolumn{1}{c|}{ TB } & TEAV & TNMES & TEB & BH & TBH \\
\hline $\begin{array}{l}\text { espírito de } \\
\text { Deus }\end{array}$ & $\begin{array}{l}\text { Espírito de } \\
\text { Deus }\end{array}$ & $\begin{array}{l}\text { força ativa } \\
\text { de Deus }\end{array}$ & $\begin{array}{l}\text { sopro de } \\
\text { Deus }\end{array}$ & $\begin{array}{l}\text { espírito de } \\
\text { Deus }\end{array}$ & $\begin{array}{l}\text { Ruach de } \\
\text { Elohim }\end{array}$
\end{tabular}

A TB, a TEAV e a BH trazem "Espírito de Deus”, que é a tradução já consagrada de Ruach Elohim. A TEB traz "sopro de Deus”, variação que pode ser explicada pela polissemia do termo hebraico ruach, que pode significar, além de espírito, também vento, mente, sopro ou fôlego. Já na TNMES, nota-se um desvio 
semântico na tradução de ruach, pois, já descontando a polissemia, percebe-se que “força ativa” parece não corresponder a nenhum dos significados desse termo. Quais seriam as implicações ideológico-doutrinárias dessa decisão dos tradutores da TNMES?

Na visão tradicional do Cristianismo, o Espírito de Deus em Gênesis 1:2 tem sido interpretado como uma referência à terceira pessoa da Trindade (o Espírito Santo). Mas as Testemunhas de Jeová não compactuam com esse dogma, conforme está dito no livreto doutrinário O que Deus requer de nós? (1996, p. 22): "é Jeová uma Trindade - três pessoas em um só Deus? Não! ... Deus não é uma Trindade... O espírito santo não é pessoa; é a força ativa de Deus”. Dessa forma, ao terem traduzido o termo hebraico ruach por "força ativa", percebe-se que os tradutores da TNMES, além de terem se afastado das palavras do original, incluíram no texto de chegada uma crença que é peculiar às Testemunhas de Jeová.

\subsubsection{Uma profecia messiânica?}

Consideremos a tradução literal do hebraico para Isaías 9:6, tomada de Kohlenberger III (1987, p. 19):

Pois [uma] criança nasceu a nós, [um] filho foi dado a nós, e estará a autoridade sobre seu ombro, e será chamado seu nome Maravilha de Conselheiro, Deus de Poder, Pai da Eternidade, Príncipe da Paz.

Levando em conta o que Gabel e Wheeler (2003, p. 229) denominam de dimensão religiosa do texto bíblico, a leitura tradicional do Cristianismo quanto a essa passagem é que se trata de uma das profecias messiânicas que teriam se cumprido na pessoa de Jesus de Nazaré. Uma das justificativas apresentadas para esse pensamento é que Mateus 4:16, passagem que o evangelista registra antes de começar a narrar como se deu o início do ministério de Cristo, nada mais é do que uma citação direta de Isaías 9:2, que, por sua vez, seria o versículo que introduz a profecia messiânica da qual Isaías 9:6, que estamos analisando, é parte integrante. Isto posto, vejamos como nosso corpus traduziu os excertos sublinhados da tradução literal:

\begin{tabular}{|c|c|c|c|c|c|}
\hline TB & TEAV & TNMES & TEB & $\mathrm{BH}$ & TBH \\
\hline $\begin{array}{l}\text {... a nós } \\
\text { nos é } \\
\text { dado um } \\
\text { filho... }\end{array}$ & $\begin{array}{l}\text {...um filho } \\
\text { nos foi } \\
\text { dado... }\end{array}$ & $\begin{array}{l}\ldots \text { um filho } \\
\text { se nos deu... }\end{array}$ & $\begin{array}{l}\ldots \text { um filho } \\
\text { nos foi } \\
\text { dado... }\end{array}$ & $\begin{array}{l}\text {...um filho (de } \\
\text { Ahaz [Acaz], } \\
\frac{\text { da dinastia de }}{\text { David) nos foi }}\end{array}$ & $\begin{array}{l}\text {...um } \\
\text { filho se } \\
\text { nos } \\
\text { deu... }\end{array}$ \\
\hline $\begin{array}{l}\text {...ele tem } \\
\text { por } \\
\text { nome... }\end{array}$ & $\begin{array}{l}\text {...ele se } \\
\text { chama... }\end{array}$ & $\begin{array}{l}\text {...será } \\
\text { chamado } \\
\text { pelo nome... }\end{array}$ & $\begin{array}{l}\text {...proclama- } \\
\text { se o seu } \\
\text { nome... }\end{array}$ & $\begin{array}{l}\text { dado... } \\
\text {...alcunhou-o } \\
\text { (a Hizikiáhu } \\
\text { [Ezequias], o } \\
\underline{\text { filho de }} \\
\underline{\text { Ahaz).... }}\end{array}$ & $\begin{array}{l}\text {...se } \\
\text { chamará } \\
\text { o seu } \\
\text { nome... }\end{array}$ \\
\hline
\end{tabular}


$\mathrm{O}$ quadro nos mostra que a $\mathrm{BH}$ desviou-se das palavras do original, pois introduziu interpolações, no intuito de revelar a suposta identidade do filho que a profecia diz que nasceria (Ezequias). De fato, levando em conta o que Gabel e Wheeler (2003, p. 223) chamam de dimensão histórico-literária da Bíblia, alguns comentaristas acreditam que Isaías estava descrevendo um governante judeu que viria durante o seu próprio tempo. Entre os nomes que já foram sugeridos, está justamente o de Ezequias. Por outro lado, há comentaristas defendendo que estamos diante de uma profecia de duplo cumprimento: na esfera histórico-literária, estaria se referindo ao nascimento de um futuro rei que governaria Israel já na época de Isaías. Já na esfera religiosa, a passagem seria uma referência ao nascimento do Messias, visto que o texto fonte atribui epítetos sobre-humanos à criança que nasceria, tais como "Deus de Poder" e "Pai da Eternidade".

Quais seriam as implicações ideológico-doutrinárias que levaram os tradutores da $\mathrm{BH}$ a se afastarem das palavras do texto fonte? Parece, pois, que estamos diante de um esforço para negar a visão cristã acerca dessa passagem, já que o Cristianismo costuma se valer dela para afirmar que se trata de uma referência a Cristo. Assim, a maneira peculiar de traduzir Isaías 9:6 foi provavelmente com o intuito de romper uma potencial associação da passagem com a pessoa de Jesus de Nazaré, que não é visto como Messias pelo público-alvo da $\mathrm{BH}$ (os judeus tradicionais).

3.3.4. Atitude dos ninivitas diante da pregação do profeta Jonas ${ }^{4}$

Consideremos a tradução interlinear do grego para Mateus 12:41, conforme apresentada por Gomes e Olivetti (2008, p. 48):

Homens ninivitas levantar-se-ão em o juízo com a geração esta $e$ condenarão ela, porque arrependeram-se com a pregação de Jonas, e eis algo maior que Jonas (está) aqui.

Nesta passagem, Cristo está declarando qual teria sido a atitude dos que ouviram o profeta Jonas, atitude que está sendo designada pela palavra grega metanoeo. Esse verbo no grego contém duas ideias: mudar de opinião e sentir remorso. Costuma-se traduzi-lo por arrepender-se, por ser o termo que parece mais se aproximar do conceito original. Vejamos agora como nosso corpus traduziu o verbo metanoeo:

\begin{tabular}{l|l|l|l|l}
\multicolumn{1}{c|}{ TB } & TEAV & \multicolumn{1}{c|}{ TNMES } & \multicolumn{1}{c|}{ TEB } & TBH \\
\hline $\begin{array}{l}\text { se } \\
\text { arrependeram }\end{array}$ & $\begin{array}{l}\text { fizeram } \\
\text { penitência }\end{array}$ & $\begin{array}{l}\text { arrependeram- } \\
\text { se }\end{array}$ & $\begin{array}{l}\text { converteram- } \\
\text { se }\end{array}$ & $\begin{array}{l}\text { arrependeram- } \\
\text { se }\end{array}$
\end{tabular}

\footnotetext{
${ }^{4}$ A partir daqui, daremos início aos exemplos de passagens retiradas do chamado Novo Testamento. Sendo assim, a Bíblia Hebraica (BH) ficará de fora, pois essa tradução contém apenas a parte que os cristãos chamam de Antigo Testamento.
} 
Três versões usaram o termo mais recomendado da língua alvo (TB, TNMES e TBH). E duas traduziram de uma maneira distinta (a TEAV e a TEB). A TEB optou por uma palavra que denota um conceito mais amplo (a conversão), no qual a Teologia diz que o arrependimento estaria contido. Já quanto à TEAV, notase um distanciamento maior do significado de metanoeo, visto que está dito que os personagens fizeram penitência. O sacramento da penitência nada mais é do que um dos dogmas da Igreja Católica, patrocinadora da tradução da TEAV. É um conceito bastante complexo, que envolve o reconhecimento do pecado, a confissão e castigos impostos pelo sacerdote. Ou seja, são ideias aparentemente não abarcadas pelo verbo grego. Apesar disso, é provável que a expressão fizeram penitência tenha sido escolhida para atender às expectativas do projeto tradutivo em trazer à luz uma versão que refletisse os dogmas da Igreja Católica em lugares específicos do texto de chegada.

\subsubsection{O camelo e o fundo da agulha}

Vejamos o que diz a tradução literal do grego para Mateus 19:24, tomada de Gomes e Olivetti (2008, p. 80):

De novo, digo a vós: Mais fácil é um camelo por um buraco de uma agulha entrar do que um rico em o reino de Deus entrar.

Vejamos agora como nosso corpus traduziu o trecho sublinhado:

\begin{tabular}{|c|c|c|c|c|}
\hline TB & TEAV & TNMES & TEB & $\mathrm{TBH}$ \\
\hline $\begin{array}{l}\text {...mais fácil } \\
\text { é passar um } \\
\text { camelo } \\
\text { pelo fundo } \\
\text { de uma } \\
\text { agulha... }\end{array}$ & $\begin{array}{l}\text {...é mais fácil } \\
\text { um camelo } \\
\text { passar pelo } \\
\text { fundo de uma } \\
\text { agulha... }\end{array}$ & $\begin{array}{l}\text {...é mais fácil } \\
\text { um camelo } \\
\text { passar pelo } \\
\text { orifício duma } \\
\text { agulha... }\end{array}$ & $\begin{array}{l}\text {...é mais fácil } \\
\text { um camelo } \\
\text { passar pelo } \\
\text { buraco de uma } \\
\text { agulha... }\end{array}$ & $\begin{array}{l}\text {...é mais } \\
\text { fácil passar } \\
\text { uma corda } \\
\text { pelo fundo } \\
\text { de uma } \\
\text { agulha... }\end{array}$ \\
\hline
\end{tabular}

Ao contrário do texto fonte e das demais versões do corpus, na TBH, é uma corda que passa pelo fundo de uma agulha, e não um camelo. Naturalmente, poder-se-ia concluir que estamos diante de uma tradução equivocada. Mas essa divergência tem uma explicação ideológico-doutrinária: uma inclinação à hipótese da primazia aramaica, a qual defende que os livros do NT foram escritos em aramaico, e depois traduzidos para o grego, mas os supostos originais aramaicos teriam se perdido, e somente a tradução para o grego sobreviveu.

Neste caso, segundo os defensores da primazia aramaica, o termo camelo no texto grego do NT de que dispomos seria um equívoco de tradução, originado pela palavra aramaica ambígua gamla, que podia significar tanto camelo quanto corda. Assim, ao apresentarem uma tradução diferenciada, os tradutores da TBH demonstram estarem defendendo que o sentido correto da palavra é corda. No entanto, a hipérbole de um grande animal passando pelo buraco de uma agulha é uma analogia de cunho oriental, usada em outros escritos religiosos orientais, como o Talmude dos judeus e o Alcorão dos muçulmanos. Isso indica que não há como 
saber ao certo se a referência em Mateus 19:24 foi a uma corda ou a um camelo. Porém, os tradutores favoráveis à primazia aramaica estarão propensos a deixar de lado a informação que conta no texto grego do NT e substituí-la por aquela que se encaixa na sua corrente ideológico-doutrinária.

3.3.6. A pontuação das línguas modernas como sinalizadora de marcas ideológicodoutrinárias

Consideremos o que diz a tradução literal do grego para Lucas 23:43, segundo Gomes e Olivetti (2008, p. 344):

Disse-lhe Jesus em verdade digo a ti hoje estarás junto a mim no paraíso.

Nota-se que esta frase é ambígua, pois não há como saber ao certo se o advérbio "hoje” está modificando o verbo dizer ou o verbo estar. A pergunta então que se coloca é: Cristo está prometendo ao ladrão arrependido que naquele mesmo dia ambos estariam no paraíso, após morrerem, ou era naquele dia que ele estava fazendo a promessa, sem especificar quando ambos estariam lá? Não há como saber ao certo se não for atribuída uma pontuação à sentença. E a maneira como o texto de chegada será pontuado revelará a posição ideológico-doutrinária dos tradutores quanto ao tema da vida após a morte. Vejamos, então, como nosso corpus traduziu a passagem:

\begin{tabular}{|c|c|c|c|c|}
\hline TB & TEAV & TNMES & TEB & $\mathrm{TBH}$ \\
\hline $\begin{array}{l}\text { Em verdade } \\
\text { te digo que } \\
\text { hoje estarás } \\
\text { comigo no } \\
\text { Paraíso. }\end{array}$ & $\begin{array}{l}\text { Em verdade } \\
\text { te digo: hoje } \\
\text { estarás } \\
\text { comigo no } \\
\text { paraíso. }\end{array}$ & $\begin{array}{l}\text { Deveras, eu } \\
\text { te digo hoje: } \\
\text { Estarás } \\
\text { comigo no } \\
\text { Paraíso. }\end{array}$ & $\begin{array}{l}\text { Em verdade } \\
\text { eu te digo, } \\
\text { hoje, estarás } \\
\text { comigo no } \\
\text { paraíso. }\end{array}$ & $\begin{array}{l}\text { Em êmeth te } \\
\text { digo hoje, } \\
\text { estarás } \\
\text { comigo no } \\
\text { Paraíso. }\end{array}$ \\
\hline
\end{tabular}

Em duas versões (TB e TEAV), Cristo está dizendo ao ladrão que ambos estariam no paraíso naquele mesmo dia. Por outro lado, em outras duas (TNMES e TBH), a pontuação utilizada conduz à interpretação de que Cristo não está especificando quando eles estariam lá. E a TEB, ao ter posto o termo "hoje" entre vírgulas, conseguiu manter a ambiguidade do texto original, pois não se sabe ao certo qual interpretação está sendo ali defendida. Quais as implicações ideológicodoutrinárias dessas decisões dos tradutores?

Traduções da Bíblia que procuram pontuar o texto de chegada de forma que a leitura seja que é naquele mesmo dia que os dois estariam no paraíso coincidem com a ideia de que, após a morte, a alma do ser humano permanece consciente. Por outro lado, as traduções que procuram direcionar a leitura para o viés de que o termo "hoje" se refere ao dia da promessa, estariam defendendo a ideia de que, ao morrer, o ser humano fica inconsciente e entra em uma espécie de sono. Todas as versões do corpus ficaram a favor de uma dessas duas posições ideológico-doutrinárias, exceto a TEB, pois, como vimos, não se sabe qual linha interpretativa ela está defendendo, o que é justificável quando se leva em conta que estamos diante de uma tradução ecumênica, em que os tradutores procurem ficar neutros diante de passagens controversas. 


\section{Considerações finais}

O leitor brasileiro contemporâneo tem muitas traduções bíblicas ao seu dispor, pautadas em princípios que vão desde a paráfrase livre até aqueles bastante próximos da tradução literal. Podemos até aplaudir essa pluralidade de traduções da Bíblia, pois, segundo Konings (2009, p. 108), se é verdade que cada tradução é uma traição, a pluralidade ajuda a descobrir as "traições". Conforme procuramos demonstrar por intermédio de alguns exemplos apresentados, as traduções bíblicas não estão imunes de espelhar ideologias doutrinárias, e as divergências de pensamento envolvendo os diferentes grupos religiosos presentes no Brasil acabaram por se refletir também e já na sua primeira tradução da Bíblia feita em território nacional.

Assim, percebe-se que a manipulação ideológico-doutrinária nas traduções de certas passagens da Bíblia é uma realidade e deve ser estudada, para checar em quais aspectos e em que medida os grupos religiosos estão se distanciando do texto fonte. Foi justamente nessa lacuna que residiu o objetivo primário da nossa tese. E acreditamos que os exemplos apresentados servem não só para revelar as facetas que diferenciam um grupo religioso do outro, mas também ajudam a construir a própria ideologia doutrinária de cada grupo e a mostrar que esta é fator determinante na tradução diferenciada de certas passagens.

Marcelo Raupp

mrraupp@yahoo.com.br

Doutor em Estudos da Tradução, Universidade Federal de Santa Catarina

\section{Referência bibliográfica}

RAupP, Marcelo. A história da transmissão e da tradução da Bíblia em nível mundial e no Brasil e as marcas ideológicas nas primeiras traduções brasileiras completas dessa obra. 2015. 230 p. Tese (Doutorado em Estudos da Tradução) - Programa de Pós-Graduação em Estudos da Tradução, Universidade Federal de Santa Catarina, Florianópolis, 2015. Disponível em: < http://goo.gl/3EFLvu>. 